\title{
Human impacts and eutrophication patterns during the past $\sim 200$ years at Lago Grande di Avigliana (N. Italy)
}

\author{
Walter Finsinger · Christian Bigler • \\ Urs Krähenbühl · André F. Lotter · \\ Brigitta Ammann
}

Received: 14 October 2005 / Accepted: 23 January 2006

(C) Springer Science+Business Media B.V. 2006

\begin{abstract}
A short sediment core from Lago Grande di Avigliana (Piedmont, Italy), the second most eutrophied lake in Italy, was analysed for pollen and diatoms to reconstruct land-use changes and to estimate baseline conditions for total phosphorus (TP) in the water column. Varve counts on sediment thinsections and ${ }^{210} \mathrm{~Pb},{ }^{226} \mathrm{Ra}$, and ${ }^{137} \mathrm{Cs}$ dating provided a reliable chronology for the past $\sim 200$ years. The main pollen-inferred land-use changes showed a sharp decrease of hemp retting around AD 1900, as well as a gradual change to less intensive agriculture and increasing abundance of exotic plants since $\mathrm{AD}$
\end{abstract}

W. Finsinger $\cdot$ B. Ammann

Institute of Plant Sciences, University of Bern,

Altenbergrain 21, CH-3013 Bern, Switzerland

A. F. Lotter - W. Finsinger $(\square)$

Laboratory of Palaeobotany and Palynology,

Utrecht University, Budapestlaan 4, 3584 CD Utrecht,

The Netherlands

e-mail: w.finsinger@bio.uu.nl

C. Bigler

Ecology and Environmental Science, KBC plan 5,

Umeå University, SE-901 87 Umeå, Sweden

C. Bigler

NCCR Climate, Institute of Plant Sciences, University of

Bern, Altenbergrain 21, CH-3013 Bern, Switzerland

U. Krähenbühl

Department of Chemistry and Biochemistry, University of

Bern, Freiestrasse 3, CH-3012 Bern, Switzerland $\sim 1970$. Diatom-inferred TP reconstructions indicated stable TP concentrations until AD $\sim 1950$, revealing baseline mesotrophic conditions (TP $<25 \mu \mathrm{g}^{-1}$ ). After AD 1950, TP values increased distinctly and continuously, culminating in the late 1960s with concentrations of $150 \mu \mathrm{g} \mathrm{l}^{-1}$. Subsequently, diatoms implied a linear decrease of TP, with an inferred value of $40 \mu \mathrm{g}^{-1}$ in the surface sediment sample. Comparison with instrumental TP measurements from the water column since AD 1980 showed a rapid recovery and allowed a direct validation of the diatom TP inference. However, although the TP concentration has decreased considerably, baseline conditions have not yet been reached. When compared to the limnological effects of sewage discharges on inferred-TP concentration, our results indicated that agricultural land use played a minor role in the lake's eutrophication.

Keywords Land-use changes - Varves .

Eutrophication $\cdot$ Pollen analysis $\cdot$ Diatom analysis . Validation · Italy

\section{Introduction}

Over the past centuries, land use has profoundly affected ecosystems. The impact of agricultural land use or of urbanisation on lake-water quality is increasingly evidenced by palaeoecological studies covering historical time-scales exceeding the time 
period of monitoring (e.g., Lotter et al. 1997; Bradbury et al. 2004). At present much attention is paid by nature conservation agencies to protect and restore ecosystems (e.g., the European Water Framework Directive, European Union 2000). If a polluted and/or disturbed lake or any other ecosystem is to be restored, a management target is needed to define natural background conditions (Lotter and Psenner 2004). Such a target can often be provided by long-term palaeoecological studies of sediment archives (e.g., Nhapi et al. 2004; Miettinen et al. 2005; Reid 2005; Sondergaard et al. 2005).

This study presents results from a high-resolution palaeoecological investigation of annually laminated sediments from Lago Grande di Avigliana (Northern Italy), which was classified as the second most eutrophied lake in Italy ( $n=147$ lakes, Gaggino et al. 1985). Despite more or less continuous seasonal chemical and biological records since 1980, no data are available on the pre-industrial conditions of the lake. Thus, an important question concerns the extent to which human impact on the terrestrial and aquatic ecosystem has changed over time.

The main aims of the present study were therefore: (i) to make an assessment of changes in the terrestrial and the aquatic environment during the past $\sim 200$ years, including the period of strongest anthropogenic eutrophication; (ii) to define pre-industrial conditions for lake-water nutrients; and (iii) eventually to verify whether the restoration procedures have been effective enough to reach pre-industrial conditions.

To achieve these aims, we used biotic (pollen and diatoms) and abiotic (loss-on-ignition) proxies. The pollen record is a classical palaeoecological tool to infer changes in vegetation and human impact on the terrestrial environment (Behre 1981; Bennett and Willis 2001). Diatoms are sensitive to changes in the environmental conditions (e.g., $\mathrm{pH}$, total phosphorus) and can be used to provide quantitative estimates of nutrient concentrations (e.g., total phosphorus, TP) in lakes (Anderson et al. 1993; Lotter 1998; Lotter et al. 1998). Finally, loss on ignition provides a qualitative estimate of sediment components (organic matter, carbonates, and residual silicates, Heiri et al. 2001).

\section{Materials and methods}

Lago Grande di Avigliana ( $353 \mathrm{~m}$ asl; $45^{\circ} 03^{\prime} 54^{\prime \prime} \mathrm{N}$, $07^{\circ} 23^{\prime} 12^{\prime \prime} \mathrm{E}$ ) is a hard-water lake located in the lower part of the Val di Susa (north-western Italy; Fig. 1). The lake is part of a complex hydrological system consisting of four aligned basins, the two outer ones being overgrown during the early to middle Holocene (Schneider 1985). It receives its water from Lago Piccolo di Avigliana. The lake characteristics are summarized in Table 1. At present the region has a characteristically temperate mid-latitude climate without any dry season. Precipitation is about $800 \mathrm{~mm} \mathrm{year}^{-1}$ with maxima occurring in spring and autumn (Biancotti et al. 1998). The tree and shrub vegetation in the flat and humid areas of the lowlands is at present dominated by Alnus glutinosa, Ulmus minor, Quercus robur, Robinia pseudacacia, and Salix alba. On the hills $Q$. pubescens occurs together with other drought-adapted species (e.g., Opuntia vulgaris, and Celtis australis) on south-exposed slopes, while cooler and moister slopes are dominated mainly by $Q$. robur and Castanea sativa. Above $\sim 600 \mathrm{~m}$, Fagus sylvatica and Abies alba occur where chestnut trees are absent (Tosco 1975).

The core (AVG 07/02) was collected from the centre of the lake (Fig. 1) in September 2002 using a freeze corer (Renberg 1981), as to preserve the fragile water-sediment interface. The frozen core was transported to the lab in a freeze-box, cleaned, photographed, and sub-sampled in $1 \mathrm{~cm}$ steps with a band saw at $4^{\circ} \mathrm{C}$ room temperature. After measuring their volume, frozen sub samples were freeze-dried and a weight corresponding to $1 \mathrm{~cm}^{3}$ was processed for pollen, diatom, and loss-on-ignition analyses and for isotope measurements.

Loss on ignition was measured every centimetre at $550^{\circ} \mathrm{C}$ and $950^{\circ} \mathrm{C}$ to estimate the amount of organic matter, carbonate content, and silicate content (expressed in \% of total dry weight) of the sediment. Samples were treated following Heiri et al. (2001). Thin-sections were prepared following the shockfreeze and freeze-dry technique (Merkt 1971; Lotter and Lemcke 1999).

The chronology is based on isotope measurements $\left({ }^{210} \mathrm{~Pb},{ }^{226} \mathrm{Ra}\right.$, and $\left.{ }^{137} \mathrm{Cs}\right)$ of freeze-dried sediment samples (Fig. 3a and 3b) and independent varve counts on thin sections (Fig. 3c). Isotope measurements were carried out in spring 2003. We used the model of Constant Rate of Supply (CRS model) for the ${ }^{210} \mathrm{~Pb}$-inferred depth-age model. Varve counts were made under a stereomicroscope with polarized 


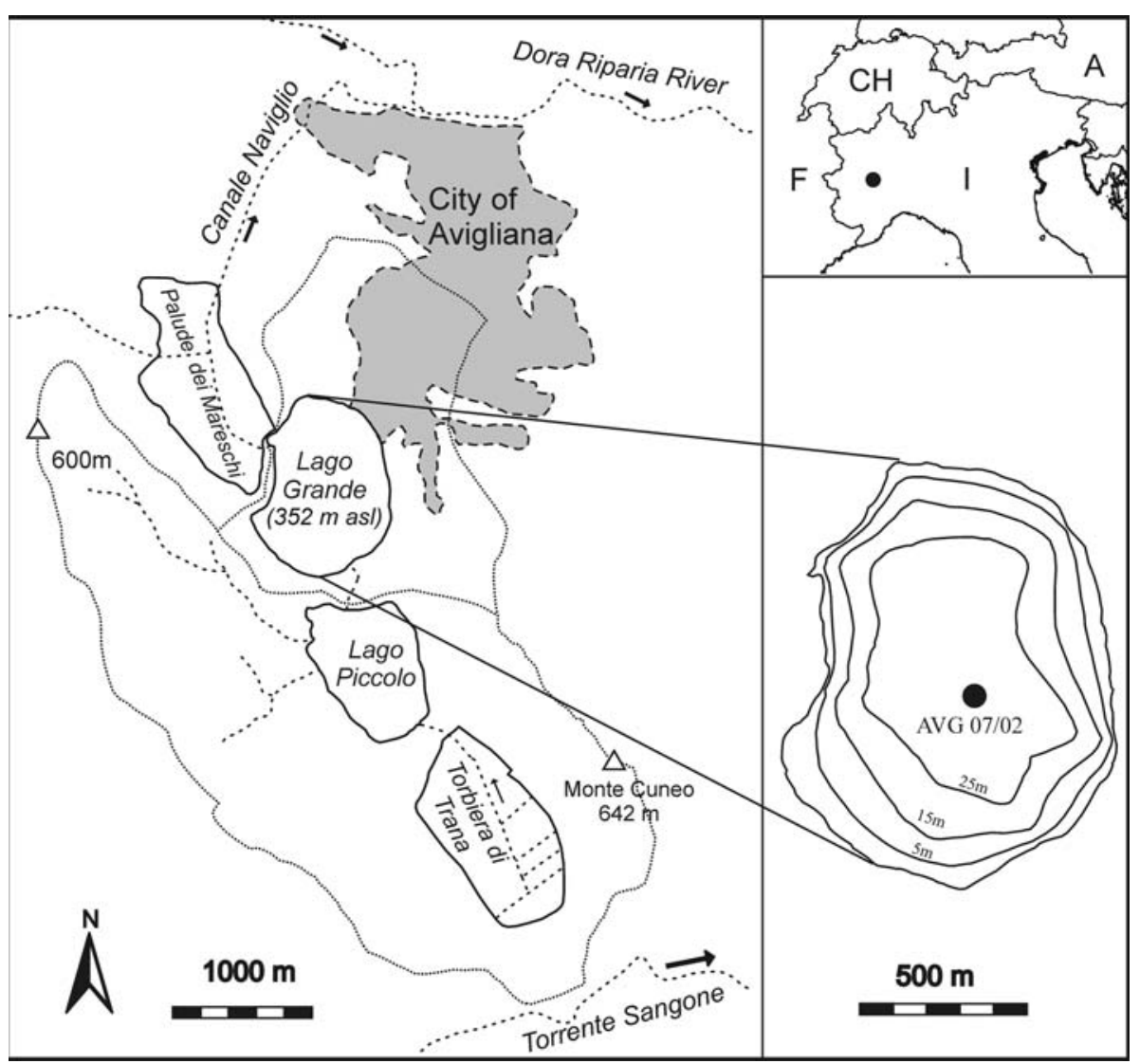

Fig. 1 Location of Lago Grande di Avigliana (grey shading: urban area) and bathymetric map of the lake basin (from Badino et al. 2001; modified) with coring location marked by the solid circle

Table 1 Morphometric, physical and hydrochemical features of Lago Grande di Avigliana (after Gaggino and Cappelletti 1984)

\begin{tabular}{ll}
\hline Elevation $(\mathrm{m}$ asl) & 352 \\
Lake surface $\left(\mathrm{km}^{2}\right)$ & 0.83 \\
Catchment area $\left(\mathrm{km}^{2}\right)$ & 10.7 \\
Length of shore line $(\mathrm{km})$ & 3.6 \\
Maximum depth $(\mathrm{m})$ & 26 \\
Mean depth $(\mathrm{m})$ & 19.5 \\
Maximum length $(\mathrm{km})$ & 1.2 \\
Maximum width $(\mathrm{km})$ & 0.8 \\
Lake volume $\left(10^{6} \mathrm{~m}^{3}\right)$ & 16.2 \\
Theor. Renew. Time $($ years $)$ & 2.3 \\
Winter-ice cover & irregular \\
pH & 7.6 \\
Min-Max TP $\left(\mu \mathrm{g} \mathrm{P} \mathrm{1} \mathrm{I}^{-1}\right)$ & $53-704$ \\
Alkalinity $\left(\mathrm{meq} \mathrm{1}^{-1}\right)$ & 2.54 \\
Conductivity $\left(\mu \mathrm{S} \mathrm{cm} \mathrm{cm}^{-1}\right)$ & 260 \\
\hline
\end{tabular}

light, by counting the spring/summer carbonate layers in increments of $10 \mathrm{~mm}$.

Preparation for pollen analysis included physical (sieving, decanting) and chemical $(\mathrm{HCl}, \mathrm{KOH}, \mathrm{HF}$, acetolysis) treatments, staining with Fuchsin, and mounting on microscopic slides with glycerol, following Lotter (1988). At least 400 pollen grains were counted at $400 \times$ magnification and identified using determination keys (Punt 1976; Moore and Webb 1978; Punt and Clarke 1980, 1981, 1984; Punt et al. 1988; Punt and Blackmore 1991) and the pollen atlas of Reille (1992, 1995). The abundance of tree, shrub, and herb pollen was calculated as the sum of terrestrial pollen, excluding pollen and spores of ferns and aquatics. As hemp plants were soaked in the lake for retting prior to further processing (Badino et al. 2001), the Cannabis/Humulus pollen type was excluded from the pollen sum because changes in its abundance are not thought to be related to its abundance in the vegetation.

Diatom preparation followed standard procedures, involving treatment with $\mathrm{H}_{2} \mathrm{O}_{2}(30 \%)$ and $\mathrm{HCl}$ $(10 \%)$, followed by heating for $>7 \mathrm{~h}$ at $70^{\circ} \mathrm{C}$ (Renberg 1990; Battarbee et al. 2001). After rinsing 
the samples with distilled water, they were dried onto cover slips and permanently mounted using Naphrax ${ }^{\circledR}$. Enumeration of diatoms ( 400 frustules per sample) was done using a Leica DMR microscope at $1000 \times$ magnification with phase contrast optics. Diatom taxonomy follows largely Krammer and Lange-Bertalot (1986, 1988, 1991a, b).

Pollen and diatom diagrams were zoned by optimal partitioning using sum-of-squares criteria (Birks and Gordon 1985). The number of significant zones was assessed by comparison with the broken-stick model (Bennett 1996).

For the TP reconstruction, subfossil diatom taxa occurring at least in one sample with abundance $>1 \%$ were selected. The selected diatom taxa $(n=27)$ represented at least $94 \%$ of the subfossil diatom assemblages and were all represented in the modern diatom calibration set. The TP reconstruction was performed using the Swiss diatom calibration set including 72 modern samples, covering an epilimnetic spring TP range from 5 to $520 \mu \mathrm{g}^{-1}$ (Lotter et al. 1998). Following Lotter et al. (1998), we used a two component WA-PLS model, characterised by a jack-knifed $r^{2}$ of 0.79 and a root-mean-square-errorof-prediction (RMSEP) of $0.19 \log _{10} \mu \mathrm{g}$ TP $1^{-1}$. Prior to calibration and reconstruction, diatom data were square-root- and TP data log-transformed. Additional details on calibration set properties and transfer function development are available in Lotter et al. (1998), for general information on numerical methods see ter Braak and Juggins (1993), ter Braak et al. (1993) and Birks (1995, 1998).

\section{Management history of Lago Grande di Avigliana}

In 1985, Lago Grande di Avigliana was classified as the second most eutrophied lake (among 147 examined lakes) in Italy (Gaggino et al. 1985). TP concentrations were ca. $220-230 \mu \mathrm{g} \mathrm{I}^{-1}$. The principal cause leading to the eutrophication was the presence of water collectors which discharged part of the sewage from the drain network of the city of Avigliana (Gaggino et al. 1985; Calderoni and Marchetto 1998). In contrast, between 1876 and $\sim 1950 \mathrm{AD}$, water quality of the lake was good and inhabitants used it as drinking water (Badino et al. 2001). Therefore, parts of the drain network were deflected into the Doria Riparia River starting from $\sim 1980 \mathrm{AD}$ in order to avoid the drain of polluted water into Lago Grande di Avigliana. However, the network was definitely deflected only in $1994 \mathrm{AD}$, when the construction of a circular sewage collector was accomplished.

Starting from 1923 AD, the "Consorzio Irrigatorio delle Gerbole di Rivalta e Paesi Limitrofi”, pumped approximately 4 millions $\mathrm{m}^{3}$ water year ${ }^{-1}$ to irrigate the surrounding agricultural fields (500 ha). Water was extracted starting in June until autumn and transferred to the Lago Piccolo di Avigliana (Fig. 1). However, due to the eutrophication of Lago Grande di Avigliana, this resulted in the eutrophication of the upstream Lago Piccolo di Avigliana, too. Therefore, starting in $1994 \mathrm{AD}$, water was extracted from Lago Grande di Avigliana from a hypolimnetic station (20 m water depth) and transferred directly into the sewage-system of the Consorzio. In this way nutrientrich water was extracted from the hypolimnion of the lake and used to fertilize the fields. According to water-quality monitoring studies, the lakes' water quality was partially re-established in $1999 \mathrm{AD}$ (Badino et al. 2001).

\section{Results and discussion}

Loss on ignition

The main sediment mass consists of the non-ignited sediment fraction (mainly silicate minerals) (Fig. 2). Carbonate content and organic matter vary generally between $10 \%$ and $20 \%$ of dry weight. Two notable interruptions are evidenced by increases in the ignition residue at $41.5-46.5 \mathrm{~cm}$ and at $33.5-35.5 \mathrm{~cm}$ depth, which match two visually identified turbidities. In addition, a major reduction of the ignition residue is recorded at $\sim 30 \mathrm{~cm}$ depth, likely indicating reduced minerogenic input from the catchment due to a decrease in erosion. In the topmost $6 \mathrm{~cm}$ (i.e., from $\sim 1975$ to the present), a gradual decrease of the ignition residue accompanied by increase of organic matter indicates a modest increase of productivity in the lake.

Sediment chronology

The chronology is based on isotope measurements $\left({ }^{210} \mathrm{~Pb},{ }^{226} \mathrm{Ra}\right.$, and ${ }^{137} \mathrm{Cs}$ ) (Fig. 3a, b) and on independent varve counts on thin sections. The inferred 
Fig. 2 Loss on ignition (values in \% of dry weight) of core AVG 07/02

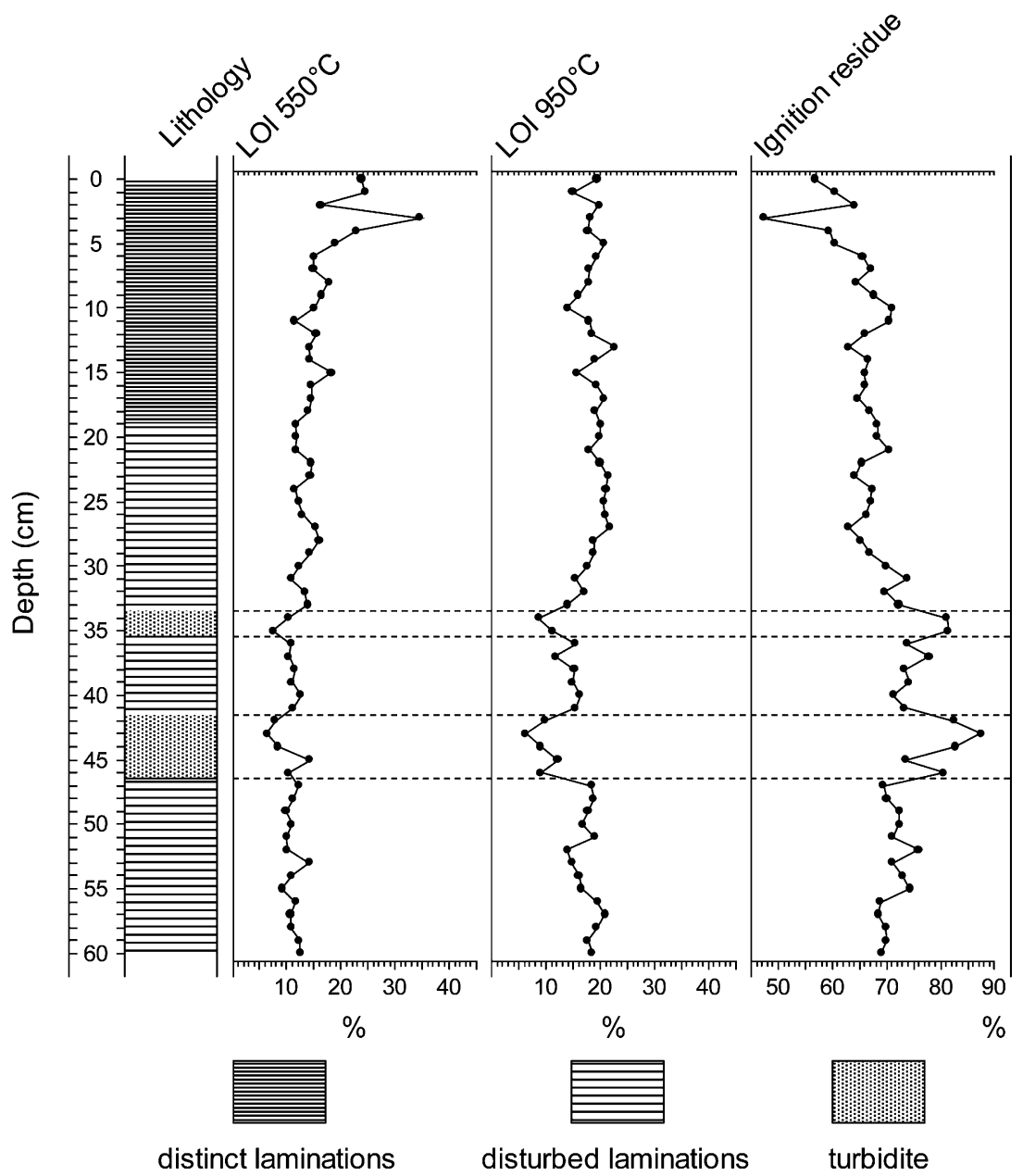

depth-age model (Fig. 3c) is referred to corrected depths obtained after the elimination of the turbidities located at $41.5-46.5 \mathrm{~cm}$ and at $33.5-35.5 \mathrm{~cm}$ depth (Fig. 2). Distinct ${ }^{137}$ Cs peaks mark the 1986 Chernobyl event (at $3 \mathrm{~cm}$ depth) and the fallout peak from the atmospheric nuclear weapons tests in 1963 (at $11 \mathrm{~cm}$ depth). The inferred accumulation rate between the two ${ }^{137} \mathrm{Cs}$ peaks (at 1963 and at 1986) is approximately $3.47 \mathrm{~mm}$ year ${ }^{-1}$. Total ${ }^{210} \mathrm{~Pb}$ activity plotted on a logarithmic scale versus depth shows constant values similar to supported ${ }^{210} \mathrm{~Pb}$ below $\sim 22 \mathrm{~cm}$, eventually dating $\sim 1850 \mathrm{AD}$ at that depth. The mean inferred accumulation rate between $22 \mathrm{~cm}$ and $10 \mathrm{~cm}$ depth is ca. $0.97 \mathrm{~mm} \mathrm{year}^{-1}$, while a higher rate $\left(2.27 \mathrm{~mm} \mathrm{year}^{-1}\right)$ was obtained for sediments between $10 \mathrm{~cm}$ and $0 \mathrm{~cm}$. The isotope-inferred models and the varve count agree well between $0 \mathrm{~cm}$ and $14 \mathrm{~cm}$, while below that depth ${ }^{210} \mathrm{~Pb}$-inferred ages appear older than varve counts. However, the sediment composition as inferred from loss-onignition measurements does not indicate a substantial change at $14 \mathrm{~cm}$ depth. Therefore, the varve-inferred accumulation rate was extrapolated downcore. The validation with pollen-inferred time markers (e.g., Cannabis sativa pollen declines and Ambrosia pollen) indicates that the extrapolated model eventually overestimates the sediment age by maximum $\sim 20$ years (Fig. 3c).

Pollen stratigraphy and inferred land-use

Overall, 120 different pollen-types were identified in sediment samples of Lago Grande di Avigliana (Fig. 4). Due to the distance to littoral vegetation, pollen of aquatic plants was extremely rare. Four statistically significant pollen assemblage zones were 

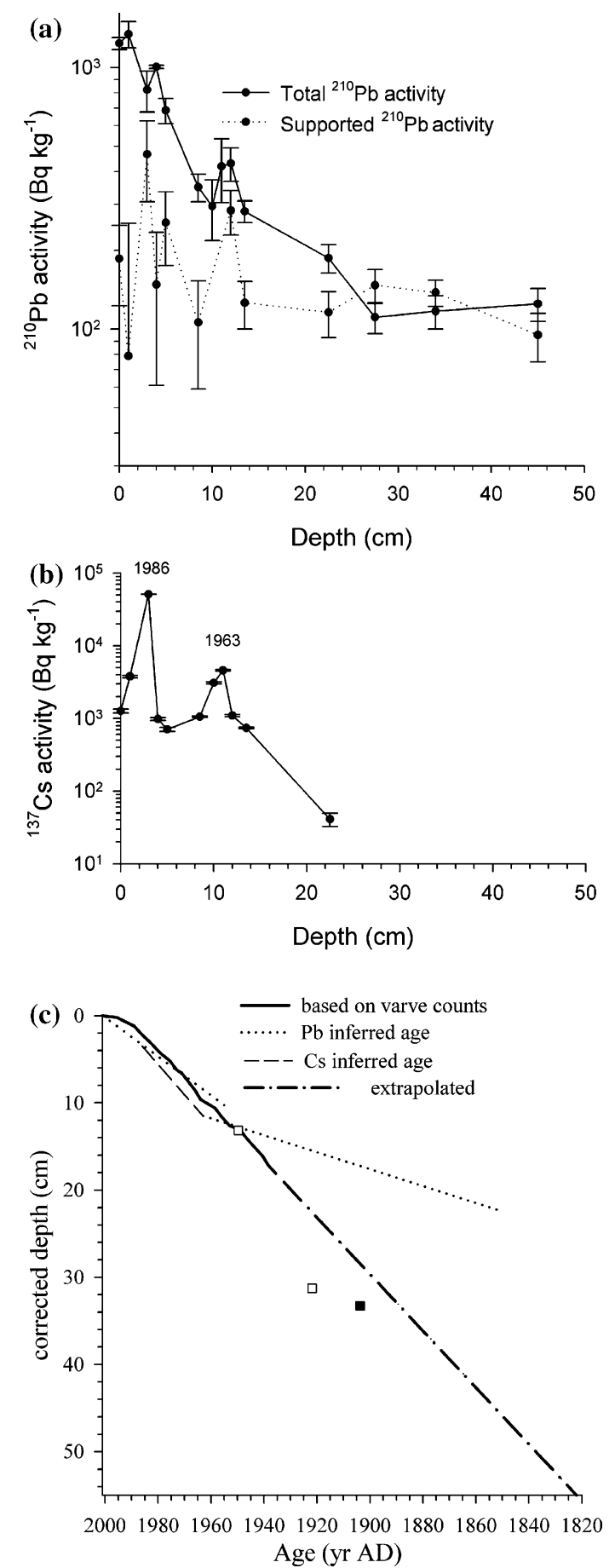

Fig. 3 (a) Total and supported ${ }^{210} \mathrm{~Pb}$ activity, (b) ${ }^{137} \mathrm{Cs}$ activity, and (c) depth-age model based on isotopes and on varve counts in sediment thin sections (see legend). $\square=$ expected age for changes in Cannabis pollen abundance; = expected age for Ambrosia pollen first appearance distinguished. These separate the gradual vegetation changes that lead from a landscape marked by farming and forest management activities to a landscape characterized by less disturbed forests and lakeshores as well as by introduced ornamental plants.

As inferred from high herb pollen values and by Juglans, Castanea, Cerealia, and Secale pollen, agriculture was intensive and the landscape was fairly open from 1830 to 1880 AD (AVG-P1; 53-35.5 cm depth). The tree pollen sum never exceeded $50 \%$ and anthropogenic indicators (e.g., Plantago lanceolata, Rumex, and Urtica) were continuously present. The presence of dry pastures is inferred from high abundances of Juniperus (Behre 1981). High amounts of Cannabis/Humulus pollen, as shown in this record, are often the result of hemp retting in lakes, a procedure necessary for the treatment of this cultivated plant prior to further processing (Bradshaw et al. 1981; Mercuri et al. 2002). Cannabis sativa cultivation and textile industries were abundant in northern Piedmont (Canavese) in the 19th century. Hemp cultivation declined in Italy starting from $\sim 1925$, and after $\sim 1950$ it further declined because of competition with synthetic fibres (Dionisi 1951). Since 1971 its cultivation is forbidden by law in Italy.

The sudden increase of Gramineae pollen marks the onset of zone AVG-P2 (35.5-18.5 cm depth; 1880-1935 AD). A further slight opening of the landscape is inferred from generally lower tree pollen values than in zone AVG-P1. This decrease was mainly due to lower percentage values of Juglans, which might indicate the abandonment of the walnut plantations. Gradually increasing values of Fraxinus excelsior may attest to its expansion in the catchment. Higher values of Populus pollen were possibly caused by its expansion in the more humid areas of the catchment, while the increase of Plantago lanceolata could indicate the persistence of disturbance. Platanus pollen is discontinuously present proving the presence of ornamental vegetation (Pignatti 1982). A strong reduction of hemp retting at $\sim 1900$ AD is inferred from the sharp decrease of Cannabis/Humulus pollen.

At $\sim 32 \mathrm{~cm}$ depth (i.e., $\sim 1890$ AD) the first pollen occurrences of Ambrosia were detected. In Piedmont two North American species of this genus, Ambrosia 
Fig. 4 Pollen

stratigraphy of Lago

Grande di

Avigliana, core

AVG 07/02. Pollen taxa are sorted by weighted average on depth and by groups

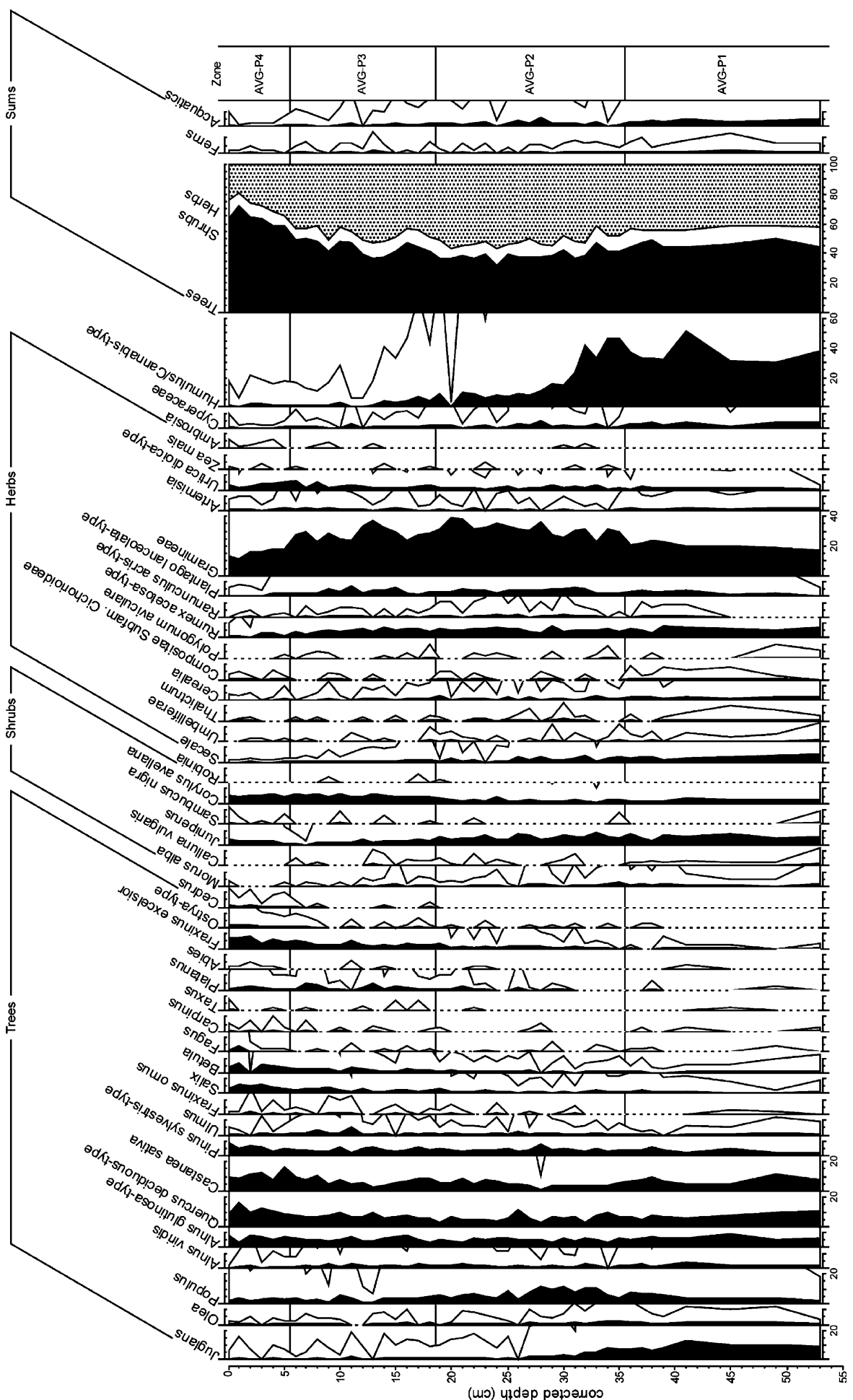

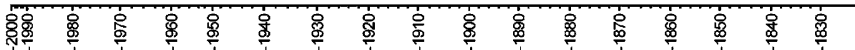
$a \forall \sin$ әक्ष 
artemisiifolia and A. trifida, occur at present on ruderal and fallow land. According to direct observations, A. artemisiifolia expanded in Piedmont starting at least in 1902 (Pignatti 1982). This is distinctly earlier than north of the Alps (e.g., van der Knaap et al. 2000).

Starting from 1935 AD (AVG-P3; 18.5-5.5 cm depth), the Gramineae pollen curve gradually decreases and the arboreal pollen curve increases from $\sim 40 \%$ to $50 \%$. In addition Secale pollen decreased after around 1960, and therefore a decrease in agricultural land is inferred. Corylus pollen increased starting from $\sim 20 \mathrm{~cm}$ depth, parallel to the decrease of Juniperus, indicating a gradual recolonisation of abandoned and ruderal patches by woody pioneers. If the expansion of pollen-unproductive urban areas did not significantly affect the pollen-inferred landscape, it implies that the landscape was gradually becoming less open than before. At the transition to zone AVG-P4 (5.5-0 cm depth; 1975-2001 AD), herbaceous pollen further decreased, while tree pollen (Fagus, Ostrya, Quercus, Salix, Cedrus and Castanea) increased. In addition, lower percentages of Plantago lanceolata and Artemisia imply that ruderal vegetation was less abundant than before. In the vegetation map of the area around the lake (Tosco 1975), Ostrya is not mentioned, possibly indicating its scarce presence. Low percentages of this pollen type in our record may however imply its presence in the surroundings at that time. According to Mondino et al. (1981) Ostrya carpinifolia was expanding in abandoned chestnut woodland and pastoral areas in Piedmont. In fact, agricultural activities in the area around Turin strongly declined between 1950 and 1970 AD because workers were more attracted by the local car industry.

Diatom stratigraphy and inferred TP changes

Overall, 85 different diatom taxa were identified and enumerated from the sediment core of the deepest part of Lago Grande di Avigliana. As could be expected, the diatom assemblages are dominated by planktonic taxa and show a typical succession found in many anthropogenically eutrophied lakes (e.g., Lotter 2001). The diatom stratigraphy was subdivided into two significant zones (Fig. 5). In the first zone (AVG-D1; 60-12 cm depth), the mesotrophic Cyclotella cyclopuncta prevailed, showing relative abundances between $40 \%$ and $80 \%$. In addition, Cyclotella comensis and Fragilaria crotonensis were the most prominent species, both showing an increasing abundance towards the end of the zone

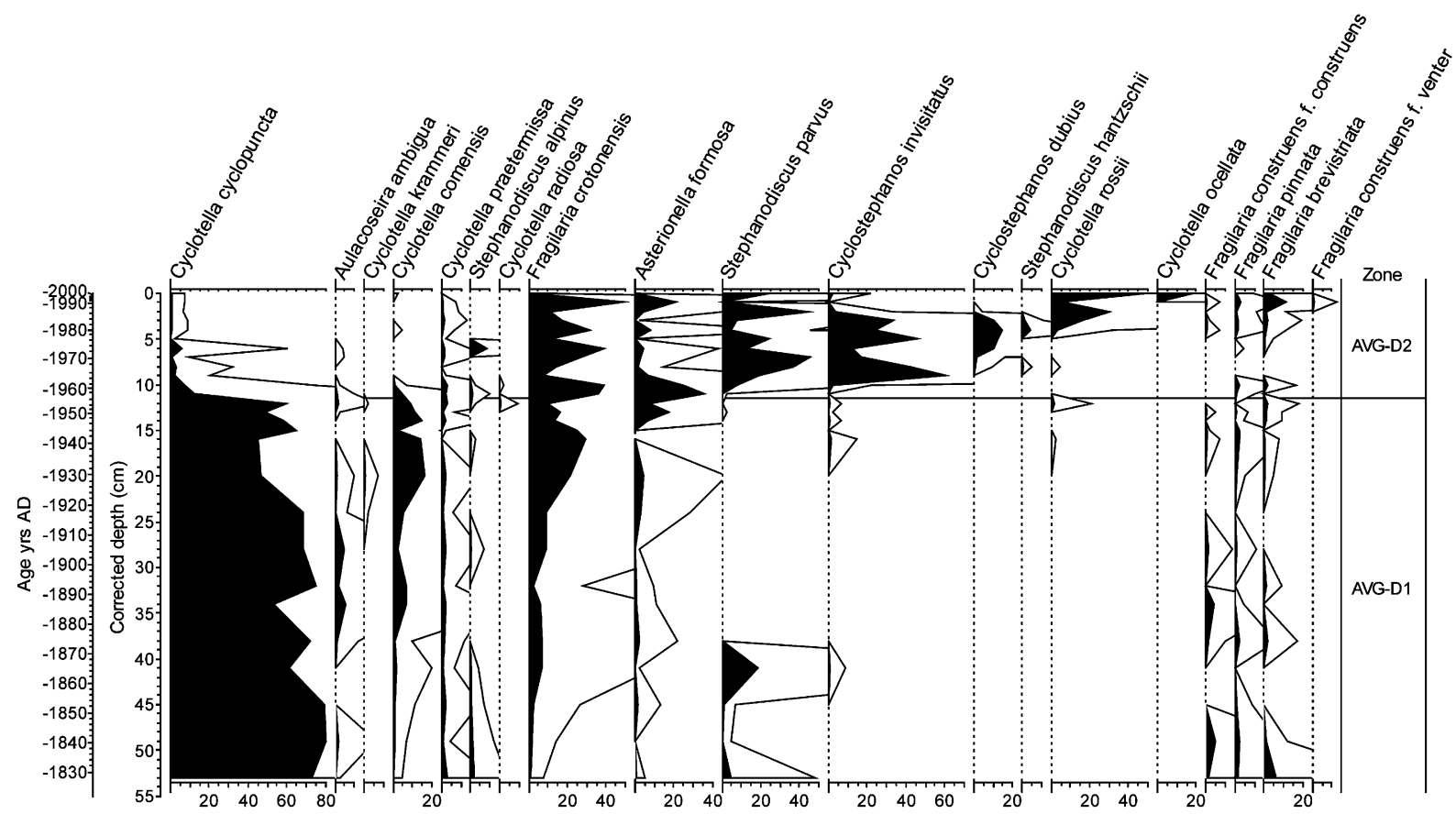

Fig. 5 Diatom stratigraphy of Lago Grande di Avigliana, core AVG 07/02. Diatom taxa are sorted by weighted average on depth 
(Fig. 5). The shift from AVG-D1 to AVG-D2 (12$0 \mathrm{~cm})$ is characterised by a sharp and dramatic decrease of Cyclotella cyclopuncta, dropping to values below $10 \%$. The small planktonic diatom taxon was replaced by other planktonic taxa preferring eutrophic conditions such as Asterionella formosa, Cyclostephanos invisitatus, C. dubius and Stephanodiscus parvus (Lotter et al. 1998). Even though AVGD2 is identified as one single zone, a distinct structure is apparent. During the initial phase, taxa tolerating high Si:P ratio (van Donk and Kilham 1990; Lotter 1998) such as Asterionella formosa and, to a certain extent, Fragilaria crotonensis, are attaining relatively high abundances. Subsequently, taxa competitive at low Si:P ratio such as Stephanodiscus and Cyclostephanos replace Asterionella formosa and partly Fragilaria crotonensis, which shows high variability during AVG-D2. The last part within the zone is characterised by a reversal of the eutrophication trend, as Stephanodiscus and Cyclostephanos are replaced by Asterionella formosa, as well as Cyclotella rossii and $C$. ocellata, two taxa preferring mesotrophic to eutrophic conditions (Lotter et al. 1998) that were not present at all in the first part of the stratigraphy (AVG-D1; Fig. 5).

The diatom-inferred TP-reconstructions suggest stable TP concentrations until 1950, indicating mesotrophic conditions (TP $<25 \mu \mathrm{g} \mathrm{l}^{-1}$ ) (Fig. 6). After 1950, a distinct and continuous increase of TP concentrations is inferred, culminating in the late 1960s at $150 \mu \mathrm{g} \mathrm{l}^{-1}$. Subsequently, diatoms imply a linearly decreasing TP trend. Surprisingly the inferred value of $40 \mu \mathrm{g} \mathrm{l}^{-1}$ in the surface sample (Fig. 6) is considerably lower than the measured value of $81 \mu \mathrm{g} \mathrm{l}^{-1}$ in $2003 \mathrm{AD}$ (Table 2).

Some TP measurements from the water column from Lago Grande di Avigliana exist (Badino et al. 1979, 2001; de Bernardi et al. 1984; Gaggino et al.

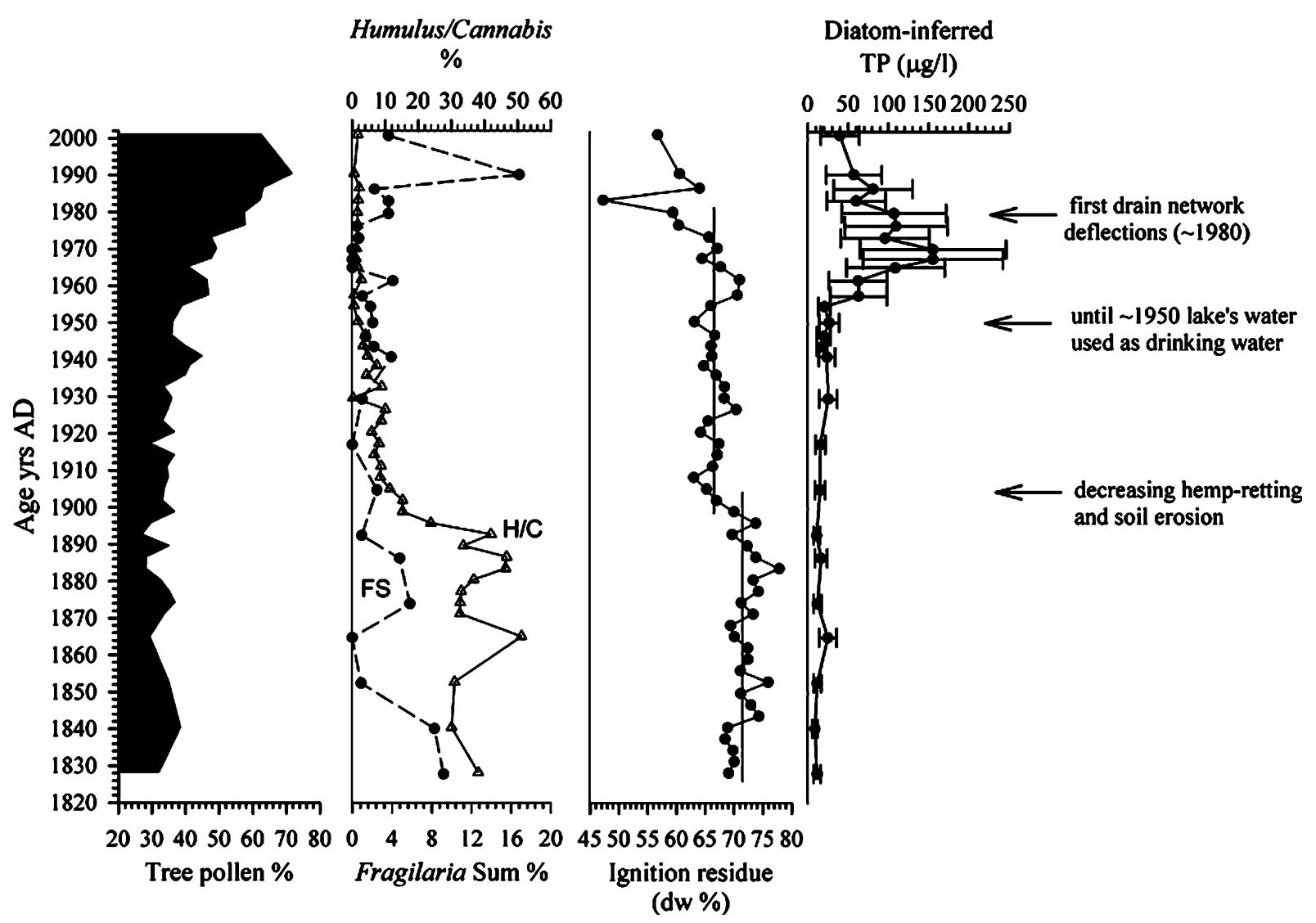

Fig. 6 From left to right: changes in forested area (tree pollen \%); Cannabis retting and Fragilaria Sum (\%); erosion activity (Ignition residue dw\%); and total diatom-inferred TP at Lago Grande di Avigliana 
1985; Defilippi 1998) (Table 2), which allow a comparison of the diatom-inferred TP values. Unfortunately, the data are, except for the past decade, sparse and heterogeneous concerning the date of sampling and the sampled water depth, hampering a direct comparison. However, two main features comparing diatom-inferences with measured TP data are visible. First, the measured TP values during the past decade support the diatom-inferred decreasing TP-concentration. Second, the diatominferred TP values are in general considerably lower than the measured data. Similarly, the same transfer function based on the Swiss calibration set underestimated the TP values of Baldeggersee (Switzerland), which was assigned to the relatively low mean TP concentration $\left(31 \mu \mathrm{g} \mathrm{l}^{-1}\right)$ of the calibration set lakes, resulting in an underestimation of high TP values (Lotter 1998). In contrast, several studies have shown an overestimation of diatominferred TP concentrations compared to measured data (e.g., Anderson and Rippey 1994; Bennion et al. 1995) at the lower end of the TP gradient. Obviously, an appropriate gradient length of the calibration set is crucial to obtain quantitatively correct reconstruction values. For comparison, we have also applied a transfer function based on the calibration set of Wunsam and Schmidt (1995), including 86 lakes from the Alps and pre-alpine regions in Northern Italy, Austria and Germany. The reconstruction shows in general the same trends as our reconstruction, but the absolute values are

Table 2 Average TP during lake circulation at Lago Grande di Avigliana

\begin{tabular}{llc}
\hline Year AD & Depth $(\mathrm{m})$ & TP $\left(\mu \mathrm{g} \mathrm{l}^{-1}\right)$ \\
\hline $14 / 01 / 2003^{\mathrm{a}}$ & mean $(0-25 \mathrm{~m} ; n=9)$ & 81 \\
$19 / 02 / 2002^{\mathrm{a}}$ & mean $(0-25 \mathrm{~m} ; n=10)$ & 77 \\
$22 / 02 / 2001^{\mathrm{a}}$ & mean $(0-25 \mathrm{~m} ; n=10)$ & 105 \\
$1999^{\mathrm{b}}$ & $?$ & 150 \\
$05 / 05 / 1998^{\mathrm{b}}$ & mean $(0-25 \mathrm{~m} ; n=9)$ & 118 \\
$22 / 02 / 1994^{\mathrm{c}}$ & mean $(0-25 \mathrm{~m} ; n=6)$ & 161 \\
$27 / 01 / 1993^{\mathrm{c}}$ & mean $(0-25 \mathrm{~m} ; n=6)$ & 200 \\
$1984^{\mathrm{d}}$ & ? & 225 \\
$26 / 03 / 1980^{\mathrm{e}}$ & mean $(0-25 \mathrm{~m} ; n=6)$ & 248 \\
$03 / 1979^{\mathrm{f}}$ & mean $(1-15 \mathrm{~m} ; n=5)$ & $353^{\mathrm{g}}$ \\
$03 / 1974^{\mathrm{f}}$ & mean $(1-15 \mathrm{~m} ; \mathrm{n}=5)$ & $290^{\mathrm{g}}$ \\
\hline
\end{tabular}

Data sources: ${ }^{\mathrm{a}}$ Dati Regione Piemonte; ${ }^{\mathrm{b}}$ Defilippi (quoted in Badino et al. 2001); ${ }^{\mathrm{c}}$ Badino et al. (2001); ${ }^{\mathrm{d}}$ Gaggino et al. (1985); ${ }^{\mathrm{e}}$ De Bernardi et al. (1984); ${ }^{\mathrm{f}}$ Badino et al. (1979); ${ }^{\mathrm{g}}$ Total orthophosphate considerably lower (data not shown). This is probably due to the low mean TP concentration of the calibration set $\left(23 \mu \mathrm{g}^{-1}\right)$. It seems that the trends of a reconstruction are less affected by the properties of the calibration set than its magnitude.

In addition to calibration-set properties and modelinherent WA-PLS problems, some reservations apply as well to measured monitoring data. The TP concentration is highly variable throughout the season and related to timing and degree of thermal stratification (e.g., Wetzel 2001). Therefore, some measured values may not reflect the accurate season and habitat for particular diatom species, particularly when considering the differences between spring- and autumnblooming taxa. Furthermore, the diatom record in the central area represents an integrated record, reflecting often more than one year and also input from littoral parts of the lake.

\section{Conclusions}

We conclude that:

(i) the diatom-inferred TP reconstruction indicates that the current TP concentration is still slightly higher than prior to 1950 . If the mean of the inferred TP values prior to 1950 is taken as a baseline measure $\left(\sim 17 \mu \mathrm{g}^{-1}\right)$, this implies that the maximum values reached in the 1960s (150 $\mu \mathrm{g}^{-1}$ or higher) were up to nine times higher, while at present inferred TP is ca. 2 times higher $\left(\sim 40 \mu \mathrm{g}^{-1}\right)$, indicating a rapid recovery of the lake's TP concentration. Hence we conclude that conservation measures (i.e., drain network deflection of sewage discharge) had a positive effect on the TP concentration of Lago Grande di Avigliana. However, pre-1950 baseline conditions have not yet been restored. The lake's diatom assemblage did not return to its previous composition, possibly owing to the incomplete recovery.

(ii) The comparison with historical TP measurements had two main outcomes. First, the measured data during the past decade support the diatom-inferred decreasing TP-concentration by showing similar trends. Second, the diatom-inferred TP values are in general lower than the measured data. This might be due either to the calibration-set properties and 
model-inherent WA-PLS features or to the high variability of TP concentration throughout the season.

(iii) As inferred from our palaeolimnological record, hemp retting was strongly reduced around $1920 \mathrm{AD}$ and was definitely abandoned $\sim 1950$. Since the abundances of Humulus/ Cannabis pollen and of inferred-TP concentration are independent, it appears that nutrient input through retting did not affect the lake TP concentration as much as the discharge of the sewage from the drain network (Fig. 6). However, retting likely had an influence on the abundance of the epiphytic Fragilaria, which have probably grown on the hemp fibres during the retting (Fig. 6). Higher ignition residue values prior to $\sim 1900 \mathrm{AD}$ might have been caused by sustained soil erosion.

(iv) The change of Secale and tree pollen abundance (Figs. 4 and 6) indicates a gradual increase of forested areas on abandoned farm/ agricultural land starting from $\sim 1960 \mathrm{AD}$. Agricultural activities in the area around Turin strongly declined between 1950 and 1970 AD because workers were more attracted by the local car industry. When compared to the limnological effects of sewage discharges on inferred-TP concentration, our results indicate that agricultural land use played a minor role.

Acknowledgments We thank Willy Tinner and Gianni Rocci for help during fieldwork, and the Parco Naturale Regionale dei Laghi di Avigliana for coring permission. We are also thankful to Gianni Musumeci for checking the petrography on the sediment thin sections. We are further indebted to Piero Guilizzoni and to Albino Defilippi for fruitful discussions and to Aldo Marchetto and an anonymous reviewer for comments. Special thanks go to Giovanni Negro and Vincenzo Pellegrino of the URP Monitoraggio Acque, Regione Piemonte, for providing the phosphorus measurements of the period 2001-2003 and to Sybille Wunsam for making her training set available. We acknowledge the Kanton of Bern and a Postdoc Fellowship of the SNF (Grant n. PBBE2-108573) who supported this research through grants to WF. This paper is Netherlands Research School of Sedimentary Geology publication 2005.12.03.

\section{References}

Anderson NJ, Rippey B (1994) Monitoring lake recovery from point-source eutrophication - the use of diatom-inferred epilimnetic total phosphorus and sediment chemistry. Freshwater Biol 32:625-639
Anderson NJ, Rippey B, Gibson CE (1993) A comparison of sedimentary and diatom-inferred phosphorus profiles implications for defining predisturbance nutrient conditions. Hydrobiologia 253:357-366

Badino G, Lodi E, Marchionni V, Rolando A (1979) Situazione ecologica e proposte di risanamento dei laghi di Avigliana e della palude dei Mareschi. Torino, pp 39

Badino G, Azzi L, Bona F, Di Natale F, Forneris G, Maffiotti A, Maiorana G, Ostacoli G, Perosino G, Tournon G (2001) I Laghi di Avigliana: prospettive di risanamento idrobiologico. Regione Piemonte - Assessorato all' Ambiente, Torino, pp 107

Battarbee RW, Carvalho L, Jones VJ, Flower RJ, Cameron NG, Bennion H, Juggins S (2001) Diatoms. In: Smol JP, Birks HJB, Last WM (eds) Terrestrial, algal, and siliceous indicators. Tracking environmental change using lake sediments. Kluwer Academic Publishers, Dordrecht, The Netherlands, pp 155-202

Behre KE (1981) The interpretation of anthropogenic indicators in pollen diagrams. Pollen Spores 23:225-245

Bennett KD (1996) Determination of the number of zones in a biostratigraphical sequence. New Phytol 132:155-170

Bennett KD, Willis KJ (2001) Pollen. In: Smol JP, Birks HJB, Last WM (eds) Terrestrial, algal, and siliceous indicators. Tracking environmental change using lake sediments. Kluwer Academic Publishers, Dordrecht, The Netherlands, pp 75-97

Bennion H, Wunsam S, Schmidt R (1995) The validation of diatom-phosphorus transfer functions: an example from Mondsee, Austria. Freshwater Biol 34:271-283

Biancotti A, Bellardone GSB, Cagnazzi B, Giacomelli L, Marchisio C (1998) Regional distribution of rainfalls and temperatures. Climatol Stud Piedmont 1:1-80

Birks HJB (1995) Quantitative palaeoenvironmental reconstructions. In: Maddy D, Brew JS (eds) Statistical modelling of quaternary science data. Quaternary Research Association XII, Cambridge, pp 161-254

Birks HJB (1998) Numerical tools in paleolimnology progress, potentialities, and problems. J Paleolimnol 20:307-332

Birks HJB, Gordon AD (1985) The analysis of pollen stratigraphical data. Zonation. In: Birks HJB, Gordon AD (eds) Numerical methods in quaternary pollen analysis. Academic Press, London, pp 47-90

Bradbury JP, Colman SM, Reynolds RL (2004) The history of recent limnological changes and human impact on Upper Klamath Lake, Oregon. J Paleolimnol 31:151-165

Bradshaw RHW, Coxon P, Greig JRA, Hall AR (1981) New fossil evidence for the past cultivation and processing of hemp (Cannabis sativa L) in Eastern England. New Phytol 89:503-510

Calderoni A., Marchetto A (1998) Stato delle conoscenze sulla situazione ambientale dei laghi piemontesi. Report CNRIII, 04.98, Istituto Italiano di Idrobiologia, Verbania Pallanza, pp 99-101

de Bernardi R, Giussani G, Mosello R, Origgi I (1984) Quadro limnologico di cinque piccoli laghi piemontesi (Avigliana, Trana, Candia, Viverone, Sirio). Doc Ist Ital Idrobiol 5:1-97 
Defilippi A (1998) Lo stato delle acque del dipartimento: relazione attività anno 1998. A.R.P.A. - Piemonte Dipartimento sub provinciale di Ivrea, pp 43

Dionisi D (1951) La canapa nell' ascolano: Segue. Tozzi Condivi, Nicola. La coltivazione della canapa. Tip. Tipolitografica, Ascoli Piceno, pp 24

European Union (2000) Directive 2000/60/EC of the European Parliament and of the Council Establishing a Framework for the Community Action in the Field of Water Policy. European Commission, off. J. Eur. Commun. L 327(2000): 1-73

Gaggino GF, Cappelletti E (1984) Lago Grande di Avigliana, Catasto dei Laghi Italiani. Quaderni dell'Istituto di Ricerca sulle Acque. Consiglio Nazionale delle Ricerche, Roma, pp 38-41

Gaggino G, Cappelletti E, Marchetti R, Calcagnini T (1985) La qualità delle acque dei laghi Italiani negli anni '80, Inquinamento e recupero dei laghi. Atti del Congresso Internazionale European water Pollution Control Association, ANDIS, Associazione Nazionale di Ingegneria Sanitaria, Roma, pp 5-32

Heiri O, Lotter AF, Lemcke G (2001) Loss on ignition as a method for estimating organic and carbonate content in sediments: reproducibility and comparability of results. J Paleolimnol 25:101-110

Krammer K, Lange-Bertalot H (1986) Bacillariophyceae. 1. Teil: Naviculaceae. G Fischer Verlag, Stuttgart, pp 876

Krammer K, Lange-Bertalot H (1988) Bacillariophyceae. 2. Teil: Bacillariaceae, Epithemiaceae, Surirellaceae. G Fischer Verlag, Stuttgart, pp 596

Krammer K, Lange-Bertalot H (1991a) Bacillariophyceae. 3. Teil: Centrales, Fragilariaceae, Eunotiaceae. G Fischer Verlag, Stuttgart, pp 576

Krammer K, Lange-Bertalot H (1991b) Bacillariophyceae. 4. Teil: Achnanthaceae, kritische Ergänzungen zu Navicula (Lineolatae) und Gomphonema. Gesamtliteraturverzeichnis Teil 1-4. G Fischer Verlag, Stuttgart, pp 436

Lotter A (1988) Paläoökologische und paläolimnologische Studie des Rotsees bei Luzern. Pollen-, grossrest-, diatomeen- und sedimentanalytische Untersuchungen. Diss Bot 124:1-187

Lotter AF (1998) The recent eutrophication of Baldeggersee (Switzerland) as assessed by fossil diatom assemblages. Holocene 8:395-405

Lotter AF (2001) The effect of eutrophication on diatom diversity: examples from six Swiss lakes. In: Jahn R, Kociolek JP, Witkowski A, Compère P (eds) Studies on diatoms. Ganter, Ruggell, pp 417-432

Lotter AF, Lemcke G (1999) Methods for preparing and counting biochemical varves. Boreas 28:243-252

Lotter AF, Psenner R (2004) Global change impacts on mountain waters: lessons from the past to help define monitoring targets for the future. In: Lee C, Schaaf T (eds) Global environmental and social monitoring. UNESCO, Paris, pp 102-114

Lotter AF, Sturm M, Teranes JL, Wehrli B (1997) Varve formation since 1885 and high-resolution varve analyses in hypertrophic Baldeggersee (Switzerland). Aquat Sci 59:304-325

Lotter AF, Birks HJB, Hofmann W, Marchetto A (1998) Modern diatom, cladocera, chironomid, and chrysophyte cyst assemblages as quantitative indicators for the reconstruction of past environmental conditions in the Alps. II. Nutrients. J Paleolimnol 19:443-463

Mercuri AM, Accorsi CA, Mazzanti MB (2002) The long history of Cannabis and its cultivation by the Romans in central Italy, shown by pollen records from Lago Albano and Lago di Nemi. Veg Hist Archaeobot 11:263-276

Merkt J (1971) Zuverlässige Auszählungen von Jahresschichten in Seesedimenten mit Hilfe von Gross-Dünnschliffen. Arch Hydrobiol 69:145-154

Miettinen JO, Simola H, Gronlund E, Lahtinen J, Niinioja R (2005) Limnological effects of growth and cessation of agricultural land use in Ladoga Karelia: sedimentary pollen and diatom analyses. J Paleolimnol 34:229-243

Mondino GP, De Biaggi E, Grisoni F, Dalmasso G, Della Beffa G, Salandin R (1981) I boschi e la Carta Forestale del Piemonte. Guida Editori, Napoli, pp 179

Moore PD, Webb JA (1978) An illustrated guide to pollen analysis. Hodder and Stoughton, London, pp 216

Nhapi I, Siebel MA, Gijzen HJ (2004) The impact of urbanisation on the water quality of Lake Chivero, Zimbabwe. J Chart Inst Water Environ Manage 18:44-49

Pignatti S (1982) Flora d'Italia. Edagricole, Bologna, pp 2324

Punt W (1976) Northwest European pollen flora. Elsevier, Amsterdam, pp 145

Punt W, Clarke GCS (1980) Northwest European pollen flora. Elsevier, Amsterdam, pp 265

Punt W, Clarke GCS (1981) Northwest European pollen flora. Elsevier, Amsterdam, pp 138

Punt W, Clarke GCS (1984) Northwest European pollen flora. Elsevier, Amsterdam, pp 396

Punt W, Blackmore S (1991) Northwest European pollen flora. Elsevier, Amsterdam, pp 275

Punt W, Blackmore S, Clarck GCS (1988) Northwest European pollen flora. Elsevier, Amsterdam, pp 154

Reid M (2005) Diatom-based models for reconstructing past water quality and productivity in New Zealand lakes. J Paleolimnol 33:13-38

Reille M (1992) Pollen et spores d'Europe et d'Afrique du nord. Laboratoire de Botanique Historique et Palynologie, Marseille, pp 520

Reille M (1995) Pollen et Spores d'Europe et d'Afrique du Nord - Supplement 1. Laboratoire de Botanique Historique et Palynologie, Marseille, pp 330

Renberg I (1981) Improved methods for sampling, photographing and varve-counting of varved lake sediments. Boreas 10:255-258

Renberg I (1990). A procedure for preparing large sets of diatom slides from sediment cores. J Paleolimnol 4:87-90

Schneider R (1985). Palynological research in the southern and southeastern Alps between Torino and Trieste. Diss Bot 87:83-103

Sondergaard M, Jeppesen E, Jensen JP, Amsinck SL (2005) Water framework directive: ecological classification of Danish lakes. J Appl Ecol 42:616-629

ter Braak CJF, Juggins S (1993) Weighted averaging partial least squares regression (WA-PLS): an improved method for reconstructing environmental variables from species assemblages. Hydrobiologia 269/270:485-502

ter Braak CJF, Juggins S, Birks HJB, van der Voet H (1993) Weighted averaging partial least squares regression (WA-PLS): definition and comparison with other methods 
for species-environment calibrations. In: Patil GP, Rao CR (eds) Multivariate environmental statistics. Elsevier Science Publishers BV, pp 525-560

Tosco U (1975) Carta della vegetazione dell'Anfiteatro morenico di Rivoli (Torino, Basse Alpi Cozie e Graie). Doc Cart Ecol 16:97-112

van der Knaap WO, van Leeuwen JFN, Fankhauser A, Ammann B (2000) Palynostratigraphy of the last centuries in Switzerland based on 23 lake and mire deposits: chronostratigraphic pollen markers, regional patterns, and local histories. Rev Palaeobot Palynol 108:85-142

van Donk E, Kilham SS (1990) Temperature effects on siliconlimited and phosphorus-limited growth and competitive interactions among 3 diatoms. J Phycol 26:40-50

Wetzel RG (2001) Limnology, lake and river ecosystems. Academic Press, Florida, pp 1006

Wunsam S, Schmidt R (1995) A diatom-phosphorus transfer function for Alpine and pre-alpine lakes. Mem Ist Ital Idrobiol 53:85-99 